\title{
Evaluation of batch mesophilic anaerobic digestion of raw and trampled llama and dromedary dungs: methane potential and kinetic study
}

\author{
M. J. Fernández-Rodríguez ${ }^{1,2} \cdot$ J. M. Mancilla-Leytón ${ }^{3} \cdot$ D. de la Lama-Calvente ${ }^{2} \cdot$ R. Borja ${ }^{2}$ (I)
}

Received: 21 September 2021 / Revised: 1 December 2021 / Accepted: 18 December 2021

(c) The Author(s) 2022, corrected publication 2022

\begin{abstract}
This research was carried out with the aim to evaluate the anaerobic digestion (AD) of llama and dromedary dungs (both untreated and trampled) in batch mode at mesophilic temperature $\left(35^{\circ} \mathrm{C}\right)$. The biochemical methane potential (BMP) tests with an inoculum to substrate ratio of 2:1 (as volatile solids (VS)) were carried out. The methane yield from trampled llama dung (333.0 $\mathrm{mL} \mathrm{CH}_{4} \mathrm{~g}^{-1} \mathrm{VS}_{\text {added }}$ ) was considerably higher than for raw llama, raw and trampled dromedary dungs (185.9, 228.4, $222.9 \mathrm{~mL} \mathrm{CH}_{4} \mathrm{~g}^{-1} \mathrm{VS}_{\text {added }}$, respectively). Therefore, trampled llama dung was found to be the best substrate for methane production due to its high content of volatile solids as well as its high nitrogen content (2.1\%) and more appropriate $\mathrm{C} / \mathrm{N}$ ratio (23.6) for $\mathrm{AD}$. The experimental data was found to be in accordance with both first-order kinetic and transference function mathematical models, when evaluating the experimental methane production against time. By applying the first-order kinetic model, the hydrolysis rate constants, $k_{h}$, were found to be $19 \%$ and $11 \%$ higher for trampled dungs in comparison with the raw dung of dromedary and llama, respectively. In addition, the maximum methane production rate $\left(R_{m}\right)$ derived from the transference function model for trampled llama dung $\left(22.0 \mathrm{~mL} \mathrm{CH}_{4} \mathrm{~g}^{-1} \mathrm{VS} \mathrm{d}^{-1}\right)$ was $83.3 \%, 24.4 \%$ and $22.9 \%$ higher than those obtained for raw llama manure and for raw and trampled dromedary dungs, respectively.
\end{abstract}

Keywords Anaerobic digestion $\cdot$ Dromedary $\cdot$ Dungs $\cdot$ Kinetics $\cdot$ Llama $\cdot$ Methane yield

\section{Introduction}

Currently, three-quarters of the global heating demand is met by coal, gas and oil, which implies a strong dependence on fossil fuels, and the rest, approximately $27 \%$, comes from renewable energy sources (bioelectricity) [1]. Considering the scenario of the energy policies announced by the members' countries of the International Energy Agency, for the coming years, world energy demand will increase by $1 \%$ per year until 2040 [2]. In order to achieve the sustainability

M. J. Fernández-Rodríguez

mjferrod@upo.es

1 Departamento de Sistemas Físicos, Químicos y Naturales, Universidad Pablo de Olavide, Ctra. de Utrera, km 1, 41013 Sevilla, Spain

2 Instituto de La Grasa (CSIC), Campus Universidad Pablo de Olavide, Edificio 46. Ctra. de Utrera, km. 1, 41013 Sevilla, Spain

3 Departmento de Biología Vegetal y Ecología, Facultad de Biología, Universidad de Sevilla, 41080 Sevilla, Spain objectives, set in 2040 [3], it is expected that renewable sources (mainly photovoltaic solar energy) will supply more than half of this growth, and natural gas, driven by the increase in trade in liquefied natural gas (LNG), will represent another third [4].

Developed countries are committed to developing, manufacturing and increasing the use of green energies, which would enhance the population life's quality by reducing the effects of climate change and aiming for a more sustainable economic development [5]. In the last 20 years, greenhouse gas (GHG) emissions generated by population growth and technological development design to new records; from 1990, global emissions have increased by almost 50\% [6]. The main source of GHG emissions is directly linked to fossil fuels being burned for the production of thermal, electrical and mechanic energy, representing two-thirds of total emissions, where transport and industry have the major impact [7].

In 2015 the United Nations designed the 17 Sustainable Development Goals (SDG) included in the 2030 Agenda with the aim to achieve a better sustainable world for all, 
"Take urgent action to combat climate change and its impacts" was included as the SDG 13 [8]. Traditional fuels (oil, coal, firewood, etc.) are still used by the rural population in developing countries [2]. These non-renewable sources are not environmentally friendly and are causing serious damage to ecosystems; the energy demands give rise to an excessive firewood consumption and deforestation [9]. At present, to provide alternative renewable energy resources that can guarantee sustainable development and reduce the adverse effects of global warming, many countries are now promoting the generation and use of bioelectricity, which is environmentally benign, as a substitute for fossil fuels (e.g. European Union set the goal of supplying 34\% of energy demands with renewable energy by 2030) [10]. Increased demand for electricity, reduced technology costs and innovative policies have enabled developing countries to take the lead in clean energy [11]. The concept of circular economy together with the green economy and bioeconomy are the centre of current discussion of international politics, whose objectives are to propose solutions to reconcile economic, environmental and social objectives [12]. The development of new conversion technologies for the use of renewable energy sources, in developing countries, can reduce the economic and environmental cost of the use of non-renewable energy; in some cases, it can provide employment and local economic growth [13].

The anaerobic digestion (AD) technology provides renewable energy (in the form of biogas; $75-80 \mathrm{vol}$. \% methane) displacing the use of traditional fuels and contributing to a reduction in global warming [14]. Biogas production from animal wastes (mainly fresh manure) is a widely studied subject. Mainly cattle and pigs' manure are a local and easy of obtained waste. The AD is a biological treatment capable of maximizing the valorization of these by-products $[15,16]$. However, no attention has been paid to other ungulate herbivores common in arid-region (sheep, goat, camelid). Although herbivore manure has been used directly as organic matter for soils, it is not recommended, due to the presence of pathogens and faecal coliforms, which can cause infectious diseases [17]. In addition, the increasingly widespread use of inorganic fertilizers and the intensity of production systems is causing an important disconnect between agriculture and livestock. Thus, more viable alternatives are required for the management of livestock wastes. In this sense, $\mathrm{AD}$, as an alternative for the use of animal wastes and obtaining renewable energy sources, is favoured by its low cost and its decentralized source for the supply of energy in homes or rural communities and also contributes to reducing GHG emissions [18].

The objective of this study was to investigate the biogas production efficiency in batch using the most common aridregion camelids (i.e. llama and dromedary) dungs (raw and trampled) in biochemical methane potential tests (BMP) under mesophilic conditions. To the best of our knowledge reaches, there is no previous literature that compares raw and trampled llama and dromedary dung. This study also evaluates the suitability of two mathematical models (i.e. first-order and transference function model) to determine the biomethane production potential, the maximum methane production rate and the lag time of the different anaerobic processes evaluated using the experimental results of methane production time.

\section{Material and methods}

\subsection{Biochemical methane potential assays}

The experiments were carried out in batch mode in $250 \mathrm{~mL}$ total volume and $210 \pm 2 \mathrm{~mL}$ working volume reactors. The reactors were kept in thermostatic baths $\left(35 \pm 2{ }^{\circ} \mathrm{C}\right)$ under constant stirring at $440 \mathrm{rpm}$. The inoculum initial volatile solids concentration was $20 \mathrm{~g} \mathrm{~L}^{-1}$. In the reactors, an inoculum to substrate ratio of 2:1 (as volatile solids) was kept. The anaerobic inoculum used was a mesophilic granular sludge from a full-scale UASB reactor treating wastewater from a brewery industry. The reactors were prepared by the addition of the inoculum and the substrate together with a micronutrient solution $[19,20]$. The main characteristics of the inoculum were $\mathrm{pH}: 7.5 \pm 0.2$, total solids (TS): $24.4 \pm 1.3$ and volatile solids (VS): $20.3 \pm 1.0$. In order to maintain anaerobic conditions, nitrogen gas was added to the reactors for $2 \mathrm{~min}$ at the beginning of the experiments $(40 \mathrm{~mL}$ of headspace volume). Then, the reactors were sealed and placed into the thermostatic baths. Then, reactors in three replicates per substrate tested were carried out. A triplicate was also placed with only inoculum, without substrate, in order to subtract the inoculum's endogenous methane production. The produced biogas was passed through a $2 \mathrm{~N}$ $\mathrm{NaOH}$ solution to retain the $\mathrm{CO}_{2}$. The displacement volume was assumed to be methane. The methane production was expressed under standard conditions of pressure and temperature $\left(0{ }^{\circ} \mathrm{C}, 1 \mathrm{~atm}\right)$ [19]. The main characteristics of the different substrates used in the experiments are shown in Table 1. As can be seen, the substrates used were llama (Lama glama) and dromedary (Camelus dromedarius) raw dungs collected from the experimental farm "Aires Africanos" located in Matalascañas, Huelva (south Spain). Trampled llama and dromedary dung were the excrements that the animals deposit on their spent beds, undergoing a natural pre-treatment due to the constant treading of these ungulates.

\subsection{Analytical methods}

Prior to $\mathrm{AD}$ process, the following parameters were analyzed in both the inoculum and substrates: total chemical oxygen 
Table 1 Main Characteristics of the substrates: llama dung (raw and trampled) and dromedary dung (raw and trampled). TS total solids, $V S$ volatile solids, $C O D$ total chemical oxygen demand

\begin{tabular}{lcccc}
\hline & Raw llama dung & Trampled llama dung & Raw dromedary dung & $\begin{array}{l}\text { Trampled } \\
\text { dromedary } \\
\text { dung }\end{array}$ \\
\hline $\mathrm{TS}\left(\mathrm{g} \mathrm{kg}^{-1}\right)$ & $920.5 \pm 1.5$ & $1039 \pm 5.2$ & $918.6 \pm 5.6$ & $922.0 \pm 2.0$ \\
$\mathrm{VS}\left(\mathrm{g} \mathrm{kg}^{-1}\right)$ & $665.3 \pm 3.0$ & $779.5 \pm 9.2$ & $747.5 \pm 3.1$ & $738.8 \pm 22.7$ \\
$\mathrm{VS} / \mathrm{TS}(\%)$ & $72.3 \pm 2.2$ & $75.0 \pm 7.2$ & $81.4 \pm 4.3$ & $80.1 \pm 12.4$ \\
$\mathrm{COD}\left(\mathrm{g} \mathrm{O}_{2} \mathrm{~kg}^{-1}\right)$ & $836.5 .0 \pm 3.3$ & $998.3 \pm 2.4$ & $914.1 \pm 11.8$ & $920.4 \pm 9.4$ \\
$\mathrm{C}(\%)$ & $37.1 \pm 1.6$ & $46.5 \pm 1.0$ & $38.1 \pm 0.2$ & $43.1 \pm 2.2$ \\
$\mathrm{~N}(\%)$ & $1.4 \pm 0.2$ & $2.0 \pm 0.0$ & $1.7 \pm 0.0$ & $1.8 \pm 0.0$ \\
$\mathrm{C} / \mathrm{N}$ & $26.8 \pm 5.5$ & $23.6 \pm 0.9$ & $22.2 \pm 0.6$ & $23.7 \pm 0.7$ \\
\hline
\end{tabular}

demand (TCOD), total and volatile solids (TS and VS, respectively) and the elemental $\mathrm{C}$ and $\mathrm{N}$ concentration, as well as the total ammonia nitrogen (TAN). After 31 days of the operation period, the following parameters were determined in the resulting digestates or process effluents: total and soluble chemical oxygen demand (COD), TS and VS, pH, alkalinity, TAN and volatile fatty acids (VFA). The methods used for the different analyses carried out were previously described by FernándezRodríguez et al. [21].

\subsection{Kinetic modelling}

Two kinetic models, i.e. first-order kinetic model (Eq. 1) and the transference function model (Eq. 2), were assessed to fit the experimental data of methane production during BMP test. Both methods were found to be suitable for these experiments.

The first-order kinetic model reflects the cumulative effect of all the reactions that occur during the real anaerobic digestion process that took place inside the reactors during the batch experiment [22, 23]. According to Egwu et al. [24], the first-order kinetic model (Eq. 1) assumes that hydrolysis is the rate-limiting step during $\mathrm{AD}$ process of complex feedstocks, and can be used to determine some useful kinetic parameters, especially the first-order hydrolysis kinetic constant, $k_{h}$ [24]:

$G=G_{\mathrm{m}} \cdot\left[1-\exp \left(-k_{\mathrm{h}} \cdot t\right)\right]$

where $G$ is the cumulative specific methane production ( $\left.\mathrm{mL} \mathrm{CH}_{4} \mathrm{~g}^{-1} \mathrm{VS}_{\text {added }}\right), G_{m}$ is the ultimate methane production ( $\mathrm{mL} \mathrm{CH}_{4} \mathrm{~g}^{-1} \mathrm{VS}_{\text {added }}$ ), and $k_{\mathrm{h}}$ is the hydrolysis kinetic constant $\left(\right.$ days $\left.^{-1}\right), t$ is the digestion time (days).

The transference function (TF) model (Eq. 2) was successfully applied by several authors for biomethanization of different organic wastes [21, 23, 25]. The model assumes that methane production is only bacterial growth rate dependent [22]:

$B=B_{\max } *\left(1-\exp \left[-\left(R_{\max }(t-\lambda)\right) / B_{\max }\right]\right)$

where $B$ is the cumulative specific methane production $(\mathrm{mL}$ $\left.\mathrm{CH}_{4} \mathrm{~g}^{-1} \mathrm{VS}_{\text {added }}\right), B_{\max }$ is the ultimate methane production ( $\mathrm{mL} \mathrm{CH}_{4} \mathrm{~g}^{-1} \mathrm{VS}_{\text {added }}$ ), $R_{\max }$ is the maximum methane production rate $\left(\mathrm{mL} \mathrm{CH}_{4} \mathrm{~g}^{-1} \mathrm{VS}_{\text {added }} \mathrm{d}^{-1}\right)$ and $\lambda$ is the lag time (days).

The statistical parameters such as the determination coefficients $\left(\mathrm{R}^{2}\right)$ and the standard errors of estimates (S.E.E.) were calculated to confirm the goodness-of-fit and the exactitude of the results for both models.

\subsection{Energy output}

The methane yields experimental data obtained in the BMP tests was used to determine the energy output by using Eq. 3 [26]:

$E_{0}=\left(P_{C H 4} * \varepsilon * \lambda_{m}\right) / V S_{\text {removed }}$

where $E_{0}$ is the Energy output in ( $\mathrm{kJ} \mathrm{g}^{-1} \mathrm{VS}$ removed $), P_{C H 4}$ is the cumulative methane production after digestion time $\left(\mathrm{m}^{3}\right), \varepsilon$ is the lower heating value of methane $(35,800 \mathrm{~kJ}$ $\left.\left(\mathrm{m}^{3}\right)^{-1} \mathrm{CH}_{4}\right), \lambda_{\mathrm{m}}$ is the energy conversion factor of methane (0.9) and $\mathrm{VS}_{\text {removed }}$ are the grams of VS removed at the end of the BMP test $\left(\mathrm{g} \mathrm{L}^{-1}\right)$.

\subsection{Statistical analysis}

A triplicate of each experiment and analysis was carried out. The results were expressed as means \pm standard deviations. The software SPSS Statistic IBM25.0 for Windows (Inc., Chicago, IL, USA) was used for all the statistical analyses performed. The bio-kinetic parameters for each experiment and mathematical adjustment were determined numerically from the experimental data obtained by non-linear regression using the software Sigma-Plot (version 11).

\section{Results and discussion}

\subsection{Physicochemical characteristics of the feedstock}

The characterization analyses of the different substrates used in the experiments are shown in Table 1. The amounts 
of TS concentration of the substrates used in the present experiments were similar $(922.0 \pm 2.0,918.6 \pm 5.6$, $920.5 \pm 1.5 \mathrm{~g} \mathrm{~kg}^{-1}$ ) for dromedary dung, trampled and raw llama, respectively. However, the TS content of the trampled llama dung was significantly higher $\left(1039.0 \pm 5.2 \mathrm{~g} \mathrm{~kg}^{-1}\right)$. Although the VS content was also similar in all substrates, it should be noted that the lowest VS content was found in raw llama dung $\left(665.3 \pm 3 \mathrm{~g} \mathrm{~kg}^{-1}\right)$, while the highest VS content was found for the trampled llama dung $\left(779.5 \pm 9.2 \mathrm{~g} \mathrm{~kg}^{-1}\right)$. The VS/TS (\%) was significantly higher for the dromedary dung than for the llama dung substrate $(81.4 \pm 4.3 \%$ and $80.1 \pm 12.4 \%$ for dromedary dung, raw and trampled, respectively and values of $72.3 \pm 2.2 \%$ and $75.0 \pm 7.2 \%$ for llama dung, raw and trampled, respectively). These values indicated the high carbon and the low mineral content of the substrates, being balanced substrates for the AD process [27]. The substrates nitrogen content was also considered optimal for the $\mathrm{AD}$ process since the $\mathrm{C} / \mathrm{N}$ ratio of all the substrates studied was within the range of 20-30, although other authors established a more restrictive ratio, placing the most optimal $\mathrm{C} / \mathrm{N}$ ratio for the $\mathrm{AD}$ process between 25 and 30 [20-28]. The $\mathrm{C} / \mathrm{N}$ content of the dungs used in these experiments were $26.8 \pm 5.5$ and $23.6 \pm 0.9$ for the llama dung (raw and trampled, respectively) and $22.2 \pm 0.6$ and $23.7 \pm 0.7$ for the dromedary dung substrates (raw and trampled, respectively). Nitrogen, within the optimal range, is also necessary for the growth of the microbial community that take parts in the different stages of the $\mathrm{AD}$ process [29].

\subsection{Digestate characterization}

The $\mathrm{pH}$ of the different digestates at the end of the BMP tests (Table 2) was $7.08 \pm 0.04$ for raw dromedary dung and $7.57 \pm 0.05$ for trampled llama dung. Intermediate values were found after $\mathrm{AD}$ of trampled dromedary dung $(7.33 \pm 0.08)$ and llama dung $(7.20 \pm 0.03)$. The $\mathrm{pH}$ found at the end of the batch experiments were within the optimal $\mathrm{pH}$ range for the methanogenic step [29]. Alkalinity is another very important parameter for the $\mathrm{AD}$ process and for the most $\mathrm{pH}$-sensitive microorganism involved during the AD process, i.e. methanogenic archaea [29]. After the experiments, it was found that the digestates continued to have a good buffering capacity, since values above $3,755.0 \pm 0.2 \mathrm{mg} \mathrm{CaCO}_{3} \mathrm{~L}^{-1}$ were obtained for raw llama dung, and values above 4,982 $\pm 290 \mathrm{mg} \mathrm{CaCO}_{3} \mathrm{~L}^{-1}$ were achieved for the digestate of trampled llama dung (Table 2). It has been reported that the optimal alkalinity value ranges from 2,500 to 5,000 $\mathrm{mg} \mathrm{CaCO}_{3} \mathrm{~L}^{-1}$; these values are able to buffer changes in $\mathrm{pH}$ within the anaerobic reactor [30]. The high, although not inhibitory (Table 2), values of ammonium found in the reactors at the end of the anaerobic processes could explain the great buffering capacity of the digestate after the experiments. Ammonium values higher than $1,160 \mathrm{mg} \mathrm{L}^{-1}$ were found in all reactors (Table 2). Another parameter that indicated the good evolution and adequate performance of the anaerobic processes of the studied substrates was that only acetic acid was found as volatile fatty acid after the experiments (Table 2). No accumulation of volatile fatty acids with longer chains was found.

\subsection{Methane yield coefficients}

The highest methane yield was obtained for trampled llama dung (333.0 $\mathrm{mL} \mathrm{CH}_{4} \mathrm{~g}^{-1} \mathrm{VS}$ ); values $45.7 \%$ and $49.3 \%$ are higher than those achieved for raw and trampled dromedary dungs, respectively (Fig. 1). These results are in accordance with the higher content of volatile solids, nitrogen and phosphorous found in llama manure when compared with dromedary manures (raw and trampled) [31]. Also, the highest biodegradability was found when the trampled llama dung was used as substrate. A value of $76.4 \pm 0.1 \%$ VS removal was found in the digestate.

Dromedary dungs achieve methane yields during the BMP tests of 222.9-228.4 $\mathrm{mL} \mathrm{CH}_{4} \mathrm{~g}^{-1} \mathrm{VS}$, which is significantly lower than that obtained from trampled llama dung (Fig. 1). This could be explained due to the lower nitrogen content $(1.7 \%)$ of dromedary dungs compared with trampled llama dung (2.1\%) indicating a lower content of easily
Table 2 Main characteristics of the digestates: llama dung (raw and trampled) and dromedary dung (raw and trampled). TS total solids, $V S$ volatile solids, $T A$ total alkalinity, TAN total ammonia nitrogen, $s C O D$ soluble chemical oxygen demand

\begin{tabular}{lllll}
\hline & Raw llama dung & Trampled llama dung & Raw dromedary dung & $\begin{array}{l}\text { Trampled } \\
\text { dromedary } \\
\text { dung }\end{array}$ \\
\hline $\mathrm{TS}\left(\mathrm{g} \mathrm{L}^{-1}\right)$ & $24.3 \pm 4.7$ & $23.4 \pm 3.8$ & $27.14 \pm 3.7$ & $26.18 \pm 1.8$ \\
$\mathrm{VS}\left(\mathrm{g} \mathrm{L}^{-1}\right)$ & $23.3 \pm 2.7$ & $20.8 \pm 0.7$ & $22.1 \pm 1.4$ & $20.5 \pm 0.6$ \\
$\mathrm{TA}\left(\mathrm{mg} \mathrm{CaCO}_{3} \mathrm{~L}^{-1}\right)$ & $3,755 \pm 24$ & $4,982 \pm 290$ & $3,952 \pm 556$ & $3,971 \pm 151$ \\
$\mathrm{pH}$ & $7.20 \pm 0.03$ & $7.57 \pm 0.05$ & $7.08 \pm 0.04$ & $7.33 \pm 0.08$ \\
$\mathrm{TAN}\left(\mathrm{mg} \mathrm{L}^{-1}\right)$ & $1,193 \pm 106$ & $1,398 \pm 20$ & $1,111 \pm 55$ & $1,160 \pm 29$ \\
$\mathrm{sCOD}\left(\mathrm{g} \mathrm{O}_{2} \mathrm{~kg}^{-1}\right)$ & $4,156 \pm 195$ & $4,916 \pm 115$ & $4,410 \pm 325$ & $4,683 \pm 136$ \\
$*$ Biodegradability $(\%)$ & $69.1 \pm 0.2$ & $76.4 \pm 0.1$ & $62.3 \pm 0.2$ & $67.8 \pm 0.2$ \\
Acetic acid $\left(\mathrm{mg} \mathrm{L}^{-1}\right)$ & $52.7 \pm 5.8$ & $125.4 \pm 31.5$ & $81.2 \pm 12.9$ & $210.7 \pm 21.9$ \\
\hline
\end{tabular}

*The biodegradability values were calculated from the percentages of volatile solid removal in the reactor 
Fig. 1 Biochemical methane potential ( $\left.\mathrm{mL} \mathrm{CH}_{4} \mathrm{~g}^{-1} \mathrm{VS}_{\text {added }}\right)$ of llama dungs (trampled and raw) and dromedary dungs (trampled and raw)



$\longrightarrow$-Trampled dromedary dung $\longrightarrow$ trampled llama dung $\multimap$ raw dromedary dung $\multimap$ raw llama dung biodegradable material, such as proteins and lipids, likely due to the differences in the diet of both animals [31, 32]. A minimum nitrogen content of $0.6 \%$ (w.w.) is recommended for a sustainable AD process; however, since this is needed to build the cell structure of the methanogenic microbiota, nitrogen content is directly related to methane production, which means that, providing an adequate $\mathrm{C} / \mathrm{N}$ ratio, the higher the nitrogen content, the higher the methane production [32]. Moreover, the lower methane yield coefficients observed in the dromedary dungs compared to the trampled llama manure could also be attributed to the lower number of extractive compounds (cumulative sum of compounds extracted by water and ethanol) contained in the dromedary dungs (12\% TS) compared to that observed in the trampled llama manure (15-25\% TS) [33].

Additionally, llama's first and second stomach compartments are able to maintain higher $\mathrm{NH}_{4+}$ concentrations compared with dromedary [34]. Therefore, the llama dungs are excreted with more nitrogen which would be used for microbial growth thereby increasing its methane productivity. Moreover, the $\mathrm{C} / \mathrm{N}$ ratio of trampled llama dung of 23.6 is optimal for a stable anaerobic process [35].

Methane yield values of $377 \mathrm{~mL} \mathrm{CH}_{4} \mathrm{~g}^{-1} \mathrm{VS}$ were recently reported by Meneses-Quelal et al. [36] in BMP tests of llama dungs at inoculum to substrate ratio of $2: 1$, which is identical to that used in the present research. In line with the results reported in the present study, this methane yield for llama dung was also higher than those reported by these authors for other manures such as Guinea pig manure (150 $\left.\mathrm{mL} \mathrm{CH}_{4} \mathrm{~g}^{-1} \mathrm{VS}\right)$ and vicuña manure $\left(250 \mathrm{~mL} \mathrm{CH}_{4} \mathrm{~g}^{-1}\right.$ VS) [36].

BMPs of dromedary dung in the range of 100-130 mL $\mathrm{CH}_{4} \mathrm{~g}^{-1} \mathrm{VS}$ were reported by Bastidas-Oyanedel et al. [37], methane yield values considerably lower than those achieved in the present study (222.9-228.4 $\left.\mathrm{mL} \mathrm{CH}_{4} \mathrm{~g}^{-1} \mathrm{VS}\right)$.
Nevertheless, Bastidas-Oyanedel et al. [37] also reported that a thermal pre-treatment carried out at $120{ }^{\circ} \mathrm{C}$ for $30 \mathrm{~min}$ resulted in a $33 \%$ increase of the methane yield. Shanableh et al. [38] also reported recently methane yield values for dromedary manure in the range of $129-160 \mathrm{~mL} \mathrm{CH}_{4} \mathrm{~g}^{-1} \mathrm{VS}$. These results demonstrated that the GHG emission could be reduced by a manure management system using $\mathrm{AD}$; mitigating the emissions from $0.61-0.91 \mathrm{~kg} \mathrm{kWh}^{-1}$ of $\mathrm{CO}_{2} \mathrm{eq}$ of conventional fossil fuel combustion to $0.52 \mathrm{~kg} \mathrm{kWh}^{-1}$ of $\mathrm{CO}_{2}$ eq [38].

Average maximum methane potential of $112 \mathrm{~mL} \mathrm{CH}_{4} \mathrm{~g}^{-1}$ VS for dromedary dung was reported by Sowunmi et al. [33], which was generally lower than that obtained in the present work and others reported in the literature. This could be related to the Abu Dhabi's weather conditions with temperatures going as high as $42{ }^{\circ} \mathrm{C}$ during summer months and as $51{ }^{\circ} \mathrm{C}$ in other emirates. Under these extreme conditions, dromedaries may have adapted to conserve the available nutrients more efficiently, therefore, producing lower nutrients dungs, resulting in low methane yield [33]. Dromedary manure composition includes proteins, cellulose, hemicellulose, crude fat, nitrogen and phosphorous, which therefore signifies that the high temperatures caused dromedary to be more efficient in nutrient utilization, thereby reducing methane potential of the manure produced.

\subsection{Estimation of the model parameters by kinetic modelling}

\subsubsection{First-order kinetic model}

Table 3 summarizes the kinetic parameters obtained from Eq. 1 for the digestion of the dromedary and llama dungs (both raw and trampled). As can be seen, the low values of the standard deviations and the high determination 
coefficient values prove the appropriate fit of the experimental results to the proposed model.

The hydrolysis rate constants obtained from the experimental data in the present study of llama dungs (0.046-0.051 day ${ }^{-1}$ ) were somewhat lower than those recently reported by Meneses-Quelal et al. [36] who achieved values of 0.080 and 0.098 in batch $\mathrm{AD}$ experiments of llama manure carried out at substrate to inoculum ratios of $1: 1$ and $1: 2$, respectively. In the present research, the substrate to inoculum ratio was 1:2 in all cases, as was also used by Meneses-Quelal et al. [36].

As it is shown in Table 3, the hydrolysis rate constant, $k_{h}$, for the trampled dungs were somewhat higher than those obtained for raw dungs, being $19 \%$ and $11 \%$ higher in the cases of dromedary and llama dungs, respectively. However, these increases were not statistically significant $(p<0.05)$.

In the same way, in the case of the llama dungs, the ultimate methane yield, $G_{m}$, for trampled dung was $67 \%$ higher than for raw dung. However, in the case of dromedary dungs, there were no significant differences between the $G_{m}$ values for trampled and raw dungs. This fact can be associated with the constituents of the VS part in the trampled llama dung and particularly with the higher nitrogen content $(2 \%)$ and others materials more easily biodegradable to digest [31].

\subsubsection{Transference function model}

Table 4 shows the transference function model parameters obtained for the four substrates tested in this study (raw and

Table 3 Kinetic parameters obtained from the first-order kinetic model in the batch anaerobic digestion experiments of llama dungs (raw and trampled) and dromedary dungs (raw and trampled)

\begin{tabular}{lllll}
\hline Substrate & $\begin{array}{l}G_{m}(\mathrm{~mL} \\
\mathrm{CH}_{4} \mathrm{~g}^{-1} \\
\text { VS })\end{array}$ & $k_{h}$ (days $\left.^{-1}\right)$ & $* \mathrm{R}^{2}$ & $* *$ S.E.E \\
\hline Raw llama dung & $256 \pm 20$ & $0.046 \pm 0.006$ & 0.9858 & 10.18 \\
Trampled llama dung & $428 \pm 18$ & $0.051 \pm 0.003$ & 0.9943 & 10.96 \\
Raw dromedary dung & $287 \pm 13$ & $0.057 \pm 0.005$ & 0.9908 & 10.09 \\
$\begin{array}{c}\text { Trampled dromedary } \\
\text { dung }\end{array}$ & $263 \pm 10$ & $0.068 \pm 0.005$ & 0.9890 & 10.13 \\
\hline
\end{tabular}

$* \mathrm{R}^{2}$, coefficient of determination; **S.E.E., standard error of estimate trampled dromedary dungs and raw and trampled llama dungs). The parameters $B_{m}, R_{m}$, and $\kappa$ were calculated for each one of the runs studied using the nonlinear regression approach with the software SigmaPlot 11.0. The low values of the standard deviations and the high determination coefficient values demonstrate the appropriate fit of the experimental data of methane production time to the suggested model. The high accuracy of prediction of the methane production by the proposed model shows that future measurement will fall within the predicted outcome for the camelid's biomass [39].

The obtained lag times $(K)$ were found to be almost zero across the board, indicating a fast consumption of the easy and most available biodegradable components of the two dungs assayed in all the AD processes studied [23].

As it is shown in Table 4, the maximum methane production rate $\left(R_{m}\right)$ for trampled llama dung $\left(22.0 \mathrm{~mL} \mathrm{CH}_{4}\right.$ $\mathrm{g}^{-1} \mathrm{VS} \mathrm{d}^{-1}$ ) was $83.3 \%, 24.4 \%$ and $22.9 \%$ higher than that obtained for raw llama manure $\left(12.0 \mathrm{~mL} \mathrm{CH}_{4} \mathrm{~g}^{-1} \mathrm{VS} \mathrm{d}^{-1}\right)$, and for raw and trampled dromedary dungs, respectively, which were practically identical (17.4 and $17.9 \mathrm{~mL} \mathrm{CH}_{4} \mathrm{~g}^{-1}$ $\mathrm{VS} \mathrm{d}^{-1}$, respectively). The highest value for $R_{m}$ achieved for trampled llama dung could be again attributed to the quality, and in particular to the higher nitrogen content (2\%), and the higher VS content present in this manure $\left(780 \mathrm{~g} \mathrm{~kg}^{-1}\right)$ compared to that contained in the raw llama $\left(665 \mathrm{~g} \mathrm{~kg}^{-1}\right)$ and raw and trampled dromedary dungs (727 and $718 \mathrm{~g} \mathrm{~kg}^{-1}$, respectively) [32].

\subsection{Energy output}

Although the $\mathrm{AD}$ is an environment-friendly process since it stabilizes the organic matter and reduces the polluting power of the substrates, it is very important that a high methane yield and an energy output are obtained during the process. The energy output has been estimated from experimental BMP data obtained in these experiments by using Eq. 3. The energy output or viability of the process is a key factor in scaling up the anaerobic digestion process. It should be taken into account that during the experiment, the inoculum had not been acclimatized to the new substrates, and therefore, the methane yield is, in general, underestimated. Energy output ranged from $14.1 \mathrm{~kJ} \mathrm{~g}^{-1} \mathrm{VS}_{\text {removed }}$ to
Table 4 Parameters of the transference function model for the four substrates studied (raw and trampled llama dungs and raw and trampled dromedary dungs)

\begin{tabular}{lllllc}
\hline Substrate & $\begin{array}{l}B_{m}\left(\mathrm{~mL} \mathrm{CH}_{4}\right. \\
\left.\mathrm{g}^{-1} \mathrm{VS}\right)\end{array}$ & $\begin{array}{l}R_{m}\left(\mathrm{~mL} \mathrm{CH}_{4} \mathrm{~g}^{-1}\right. \\
\left.\mathrm{VS} \mathrm{d}^{-1}\right)\end{array}$ & $\kappa(\mathrm{d})$ & $* \mathrm{R}^{2}$ & $* *$ S.E.E \\
\hline Raw llama dung & $254 \pm 24$ & $12.0 \pm 1.0$ & 0.07 & 0.9858 & 10.38 \\
Trampled llama dung & $426 \pm 22$ & $22.0 \pm 1.1$ & $1.88 * 10^{-9}$ & 0.9941 & 11.32 \\
Raw dromedary dung & $278 \pm 14$ & $17.4 \pm 1.1$ & 0.38 & 0.9912 & 10.08 \\
Trampled dromedary dung & $263 \pm 10$ & $17.9 \pm 0.8$ & $5.9 * 10^{-11}$ & 0.9890 & 10.33 \\
\hline
\end{tabular}

$* \mathrm{R}^{2}$, coefficient of determination; **S.E.E., standard error of estimate 
$8.7 \mathrm{~kJ} \mathrm{~g}^{-1} \mathrm{VS}_{\text {removed }}$ for trampled llama and raw llama dungs, respectively. For dromedary wastes, the energy output was $10.1 \mathrm{~kJ} \mathrm{~g}^{-1} \mathrm{VS}_{\text {removed }}$ and $11.8 \mathrm{~kJ} \mathrm{~g}^{-1} \mathrm{VS}_{\text {removed }}$ for trampled and raw dromedary dungs, respectively. Energy output values from 9.43 to $25.5 \mathrm{~kJ} \mathrm{~g}^{-1} \mathrm{VS}_{\text {removed }}$ were reported by Pasalari et al. [26] in the AD of landfill leachate after electrochemical oxidation pre-treatments. The values obtained in the present experiments were near the values previously reported. Passos et al. [40] reported an energy recovery of $4.1 \mathrm{~kJ} \mathrm{~g}^{-1}$ feedstock in the conventional AD of dairy manure. This low energy recovery is attributed to the low biodegradability of the lignocellulosic organic fraction in dairy manure. Therefore, these results indicated that the AD of llama and dromedary dungs (trampled and raw) is a feasible and suitable alternative for energy production.

\section{Conclusions}

Methane yield values in the range of $185.9-333.0 \mathrm{~mL} \mathrm{CH}_{4}$ $\mathrm{g}^{-1}$ VS were found in BMP experiments of llama and dromedary dungs (both raw and trampled) carried out at mesophilic temperature $\left(35^{\circ} \mathrm{C}\right)$. The highest value was obtained for trampled llama dung ( $\left.333.0 \mathrm{~mL} \mathrm{CH}_{4} \mathrm{~g}^{-1} \mathrm{VS}\right)$, which is attributed to its high VS and $\mathrm{N}$ contents, as well as to the appropriate $\mathrm{C} / \mathrm{N}$ ratio (23.6) for anaerobic digestion (AD) of this dung when compared to the others. Data from $A D$ experiments of these manures were well described by the first-order and transfer function models. The hydrolysis rate constants, $k_{h}$, (first-order kinetic model), for the trampled dungs were $19 \%$ and $11 \%$ higher than those obtained for raw dungs, in the cases of dromedary and llama manures, respectively. In addition, the maximum methane production rate $\left(R_{m}\right)$ (transference function model) for trampled llama dung was $83.3 \%, 24.4 \%$ and $22.9 \%$ higher than those obtained for raw llama manure and for raw and trampled dromedary dungs, respectively. It can be concluded that the $\mathrm{AD}$ of llama and dromedary dungs (trampled and raw) is a promising and beneficial option for energy production.

Acknowledgements The authors wish to express their gratitude to the regional government of Andalucía, Junta de Andalucía, Consejería de Transformación Económica, Industria, Conocimiento y Universidades (Project FEDER UPO-1380782) and the Project PID2020114975RB-100/AEI/10.13039/501100011033 financed by the Spanish Ministry of Science and Innovation for providing financial support. The authors wish to express their gratitude to the experimental farm "Aires Africanos" located in Matalascañas, Huelva (south Spain) for providing the llama (Lama glama) and dromedary (Camelus dromedarius) dungs.

Funding Open Access funding provided thanks to the CRUE-CSIC agreement with Springer Nature. Funding for open access publishing: Universidad Pablo de Olavide/CBUA. This study was funded y the project FEDER UPO-1380782 financed by the regional government of Andalucía, Junta de Andalucía, Consejería de Trasformación Económica, Industria, Conocimiento y Universidades and the project
PID2020-114975RB-100/AEI/10.13039/501100011033 financed by the Spanish Ministry of Science and Innovation.

Code availability Sigma-Plot (version 11) and SPSS Statistic IBM25.0 for Windows (Inc., Chicago, IL, USA.

\section{Declarations}

Competing interests The authors declare no competing interests.

Open Access This article is licensed under a Creative Commons Attribution 4.0 International License, which permits use, sharing, adaptation, distribution and reproduction in any medium or format, as long as you give appropriate credit to the original author(s) and the source, provide a link to the Creative Commons licence, and indicate if changes were made. The images or other third party material in this article are included in the article's Creative Commons licence, unless indicated otherwise in a credit line to the material. If material is not included in the article's Creative Commons licence and your intended use is not permitted by statutory regulation or exceeds the permitted use, you will need to obtain permission directly from the copyright holder. To view a copy of this licence, visit http://creativecommons.org/licenses/by/4.0/.

\section{References}

1. IEA (International Energy Agency), the International Renewable Energy Agency (IRENA) and the United Nations Statistics Division (UNSD), World Bank, WHO (2021) Tracking SDG 7: The Energy Progress Report. World Bank, Washington DC

2. IEA, International Energy Agency (2019) World Energy Outlook 2019, OECD Publishing, Paris. https://doi.org/10.1787/caf32f3ben. Accessed 26 July 2021

3. Goal 7- Affordable and Clean Energy, FAO-ONU https://www. sdfinance.undp.org/content/sdfinance/en/home/sdg/goal-7--affor dable-and-cleanenergy.html?utm_source $=$ EN\&utm_medium $=$ GSR\&utm_content=US_UNDP_PaidSearch_Brand_English \& utm_campaign $=$ CENTRAL\&c_src $=$ CENTRAL\&c_src $2=G S R \&$ gclid=CjwKCAjwhOyJBhA4EiwAEcJdcTHN4hcMGhKrFZG2 TgxRU085FRtq. Accessed 3 May 2021

4. Najm S, Matsumoto KI (2020) Does renewable energy substitute LNG international trade in the energy transition? Energy Econ 92:104964. https://doi.org/10.1016/j.eneco.2020.104964

5. Nižetić S, Djilali N, Papadopoulos A, Rodrigues JJ (2019) Smart technologies for promotion of energy efficiency, utilization of sustainable resources and waste management. J clean Prod 231:565591. https://doi.org/10.1016/j.jclepro.2019.04.397

6. IPCC (2019) Climate Change and Land: an IPCC special report on climate change, desertification, land degradation, sustainable land management, food security, and greenhouse gas fluxes in terrestrial ecosystems [PR Shukla, J Skea, E Calvo Buendia, V Masson-Delmotte, H-O Pörtner, DC Roberts, P Zhai, R Slade, S Connors, R van Diemen, M Ferrat, E Haughey, S Luz, S Neogi, M Pathak, J Petzold, J Portugal Pereira, P Vyas, E Huntley, K Kissick, M Belkacemi, J Malley, (eds.)]. In press

7. EPA, Environmental Protection Agency United State (2021) Global Greenhouse Gas Emissions Data https://www.epa.gov/ ghgemissions/global-greenhouse-gas-emissions-data). Accessed 14 July 2021

8. Goal 13, Climate Action, FAO-ONU https://www.sdfinance.undp. org/content/sdfinance/en/home/sdg/goal-13--climate-action.html. Accessed 2 August 2021 
9. Destek MA, Sinha A (2020) Renewable, non-renewable energy consumption, economic growth, trade openness and ecological footprint: evidence from organisation for economic Co-operation and development countries. J Clean Prod 242:118537. https://doi. org/10.1016/j.jclepro.2019.118537

10. Asmelash E, Prakash G, Gorini R, Gielen D (2020) Role of IRENA for Global Transition to 100\% Renewable Energy. In: Uyar T. (eds) Accelerating the Transition to a $100 \%$ Renewable Energy Era. Lecture Notes in Energy, vol 74. Springer, Cham. https://doi.org/10.1007/978-3-030-40738-4_2

11. Babenko V, Sidorov V, Koniaieva Y, Kysliuk L (2019) Features in scientific and technical cooperation in the field of non-conventional renewable energy. Glob J Environ Sci Manag 5(Special Issue): 105-112. https://doi.org/10.22034/GJESM.2019.05.SI.12

12. D'Amato D, Droste N, Allen B, Kettunen M, Lähtinen K, Korhonen J, Leskinen P, Matthies BD, Toppinen A (2017) Green, circular, bio economy: a comparative analysis of sustainability avenues. J Clean Prod 168:716-734. https://doi.org/10.1016/j.jclepro.2017.09.053

13. IRENA (2019) Global energy transformation: a roadmap to 2050 (2019 edition), International Renewable Energy Agency, Abu Dhabi

14. Kruczek G, Przybyła G, Ziółkowski Ł, Adamczyk WP (2019) Comparative assessment of the application of methane and biogas in energy production: an experimental and numerical investigation. Renew Energy 143:1519-1530. https://doi.org/10.1016/j.renene. 2019.05.087

15. Bi S, Hong X, Yang H, Yu X, Fang S, Bai Y, Liu J, Gao Y, Yan L, Wang L, Wang Y (2020) Effect of hydraulic retention time on anaerobic co-digestion of cattle manure and food waste. Renew Energy 150:213-220. https://doi.org/10.1016/j.renene.2019.12.091

16. García-Gen S, Wouwer AV (2021) A model-based optimisation strategy for the start-up of anaerobic co-digestion processes. Renew Energy 170:693-702. https://doi.org/10.1016/j.renene.2021.02.007

17. Fernández-Rodríguez MJ, Puntano NF, Mancilla-Leytón JM, Borja R (2021) Batch mesophilic anaerobic co-digestion of spent goat batch mesophilic anaerobic co-digestion of spent goat straw bedding and goat cheese whey: comparison with the mono-digestion of the two sole substrates. J Environ Manag 280:111733. https://doi.org/ 10.1016/j.jenvman.2020.111733

18. Vasco-Correa J, Khanal S, Manandhar A, Shah A (2018) Anaerobic digestion for bioenergy production: global status, environmental and techno-economic implications, and government policies. Bioresour Technol 247:1015-1026. https://doi.org/10.1016/j.biortech.2017.09. 004

19. Fernández-Rodríguez MJ, de la Lama-Calvente D, Jiménez-Rodríguez A, Borja R, Rincón-Llorente B (2019) Anaerobic co-digestion of olive mill solid waste and microalga Scenedesmus quadricauda: effect of different carbon to nitrogen ratios on process performance and kinetics. J Appl Phycol 31(6):3583-3591. https:// doi.org/10.1007/s10811-019-01858-x

20. de la Lama-Calvente D, Fernández-Rodríguez MJ, Llanos J, Mancilla-Leytón JM, Borja R (2021) Enhancing methane production from the invasive macroalga Rugulopteryx okamurae through anaerobic co-digestion with olive mill solid waste: process performance and kinetic analysis. J Appl Phycol. https://doi.org/10.1007/ s10811-021-02548-3

21. Fernández-Rodríguez MJ, de la Lama-Calvente D, Jiménez-Rodríguez A, Borja R, Rincón-Llorente B (2019) Influence of the cell wall of Chlamydomonas reinhardtii on anaerobic digestion yield and on its anaerobic co-digestion with a carbon-rich substrate. Process Saf Environ Prot 128:167-175. https://doi.org/10.1016/j.psep.2019. 05.041

22. Wang M, Lee E, Dilbeck MP, Liebelt M, Zhang Q, Ergas SJ (2017) Thermal pre-treatment of microalgae for biomethane production: experimental studies, kinetics and energy analysis. J Chem Technol Biotechnol 92:399-407. https://doi.org/10.1002/jctb.5018

23. Li L, Kong X, Yang F, Li D, Yuan Z, Sun Y (2012) Biogas production potential and kinetics of microwave and conventional thermal pretreatment of grass. Appl Biochem Biotechnol 166:1188-1191. https://doi.org/10.1007/s12010-011-9503-9

24. Egwu U, Oko E, Ndukwu MC, Sallis P (2021) Novel low-cost pretreatment material for enhancing the methane yield during anaerobic digestion of lignocellulosic biomass feedstocks: Experimental and kinetic study. Renew Energy 179:584-592. https://doi.org/10.1016/j. renene.2021.07.064

25. Donoso-Bravo A, Perez-Elvira SI, Fernández-Polanco F (2010) Application of simplified models for anaerobic biodegradability tests. Evaluation of pre-treatment processes. Chem Eng J 160:607614. https://doi.org/10.1016/j.cej.2010.03.082

26. Pasalari H, Esrafili A, Rezaee A, Gholami M, Farzadkia M (2021) Electrochemical oxidation pretreatment for enhanced methane potential from landfill leachate in anaerobic co-digestion process: Performance, gompertz model, and energy assessment. Chem Eng J 422. https://doi.org/10.1016/j.cej.2021.130046

27. Wang X, Duan X, Chen J, Fang K, Feng L, Yan Y, Zhou Q (2016) Enhancing anaerobic digestion of waste activated sludge by pretreatment: effect of volatile to total solids. Environ Technol (United Kingdom) 37(12):1520-1529. https://doi.org/10.1080/09593330. 2015.1120783

28. Wang X, Lu X, Li F, Yang G (2014) Effects of temperature and carbon-nitrogen $(\mathrm{C} / \mathrm{N})$ ratio on the performance of anaerobic codigestion of dairy manure, chicken manure and rice straw: focusing on ammonia inhibition. PLoS ONE 9(5):e97265. https://doi.org/10. 1371/journal.pone.0097265

29. Arif S, Liaquat R, Adil M (2018) Applications of materials as additives in anaerobic digestion technology. Renew Sustain Energy Rev 97:354-366. https://doi.org/10.1016/j.rser.2018.08.039

30. Fannin KF, Biljetina R (1987) Reactor design. In: Chynoweth DP, Isaacson R (eds) Anaerobic digestion of biomass. Elsevier Appl Sci, London, pp 109-128

31. Alvarez R, Villca S, Liden G (2006) Biogas production form llama and cow manure at high latitude. Biomass Bioenerg 30:66-75. https://doi.org/10.1016/j.biombioe.2005.10.001

32. Martí-Herrero J, Alvarez R, Cespedes R, Rojas MR, Conde V, Aliaga L, Balboa M, Danov S (2015) Cow, sheep and llama manure at psychrophilic anaerobic co-digestion with low cost tubular digesters in cold climate and high altitude. Bioresour Technol 181:238 246. https://doi.org/10.1016/j.biortech.2015.01.063

33. Sowunmi A, Mamone RM, Bastidas-Oyanedel JR (2016) Biogas potential for electricity generation in the Emirate of Abu Dhabi. Biomass Conv Bioref 6:39-47. https://doi.org/10.1007/ s13399-015-0182-6

34. Alvarez R, Liden G (2008) Anaerobic co-digestion of aquatic flora and quinoa with manures from Bolivian altiplano. Waste Manage 28:1933-1940. https://doi.org/10.1016/j.wasman.2007.11.002

35. Agustini CB, da Costa M, Gutterres M (2020) Tannery wastewater as nutrient supply in production of biogas from solid tannery wastes mixed through anaerobic co-digestion. Process Saf Environ Prot 135:38-45. https://doi.org/10.1016/j.psep.2019.11.037

36. Meneses-Quelal WO, Velazquez-Martí B, Gaibor-Chavez J, NiñoRuiz Z (2021) Biochemical potential of methane (BMP) of camelid waste and the Andean region agricultural crops. Renew Energy 168:406-415. https://doi.org/10.1016/j.renene.2020.12.071

37. Bastidas-Oyanedel JR, Sowunmi A, Schmidt JE (2018) Valorization of arid region abattoir animal waste: determination of biomethane potential. Wastes Biomass Valoriz 9:23-27. https://doi.org/10.1007/ s12649-018-0278-x 
38. Shanableh A, Abdallah M, Tayara A, Ghenai C, Kamil M, Inayat A, Shabib A (2021) Experimental characterization and assessment of bio- and thermo-chemical energy potential of dromedary manure. Biomass Bioenerg 148. https://doi.org/10.1016/j.biombioe.2021. 106058

39. Egwu U (2021) Improvement of biomethane potential of Elephant grass (Napier grass, Pennisetum purpureum Schum) by addition of biomass ash and ash-extracts as supplements. Bioresour Technol Reports 15. https://doi.org/10.1016/j.biteb.2021.100760
40. Passos F, Ortega V, Donoso-Bravo A (2017) Thermochemical pretreatment and $\mathrm{AD}$ of dairy cow manure: experimental and economic evaluation. Bioresour Technol 227:239-246. https://doi.org/ 10.1016/j.biortech.2016.12.034

Publisher's note Springer Nature remains neutral with regard to jurisdictional claims in published maps and institutional affiliations. 